\title{
The Distinction Between Statutory and Common Law Bonds in California
}

$\mathrm{T}$

$\mathrm{HE}$ increasing importance of the law applicable to surety bonds is emphasized by every new edition of the statutes of California. Each new regulation of business attempted by the legislature and each new enterprise undertaken by the government invariably requires the execution of new surety bonds to safeguard public and private interests. And with the increasing importance of this law, the problems contributing to its growth have become more complex. The magnitude of many of these obligations as well as considerations of convenience have made corporate bonds preferable to undertakings executed by individuals. Large surety companies, through the agency of talented and astute counsel, have for some time past been testing their liability in the courts under a great variety of circumstances, and much learning has brought forth many subtle distinctions. Any attempt, therefore, to define principles which should lie at the foundation of this law, should be of more than academic value.

In California the term "statutory bond" is a label of very doubtful meaning. As distinguished from "common law bond" it is a term frequently used by the courts, but a study of the ways in which it is used leads inevitably to considerable perplexity. Yet it obviously connotes so important a distinction that its proper classification merits some study. An examination of California cases in which this term has been employed seems to indicate that it has been used in at least two different senses.

Where a statute requires a bond to be executed as a condition precedent to the exercise of some right or privilege, or the doing of some act, by the principal obligor, then such bond is said to be a "statutory bond." Under such circumstances it seems to be conclusively presumed that the bond would not have been executed but for the compulsion of the statute. The result is that where the statute requiring such bond is held unconstitutional, or where such statute is held to have no application 
to the situation presented, the bond is declared to have been given without consideration and to be void. An illustration of this is found in the line of cases following Shaughnessy v. American Surety Co. ${ }^{1}$ Section 1203 of the Code of Civil Procedure, as enacted in 1893, required building contracts to be accompanied by a bond of the contractor in an amount equal to $25 \%$ of the contract price, inuring to the benefit of laborers and materialmen, and provided that a failure to execute such bond should render the owner of the property and the contractor jointly and severally liable in damages to such materialmen and laborers as were entitled to liens upon the property. ${ }^{2}$ The California Supreme Court in the case of Gibbs v. Tally ${ }^{3}$ declared that so much of this section as required a bond was unconstitutional. The court in the Shaughnessy case, in an action upon a bond given pursuant to section 1203 , denied recovery, saying:

"This bond was given to secure a statutory privilege upon conditions to its enjoyment imposed by the statute, but the privilege was a constitutional privilege, which could not be interfered with by statute. The undertaking was therefore wholly without consideration and void."

This decision was subsequently approved in other cases arising upon similar facts. ${ }^{*}$

So, also, in the earlier case of Coburn v. Townsend, ${ }^{5}$ the same rule was applied. There a plaintiff in condemnation proceedings was allowed, by order of the trial court, to take posses-

1 (1903), 138 Cal. 543, 69 Pac. 250, 71 Pac. 701.

2 Cal. Stats. 1893, p. 202.

8(1901), 133 Cal. 373, 65 Pac. 970, 60 L. R. A. 815.

4 San Francisco Lumber Co. v. Bibb (1903), 139 Cal. 192, 72 Pac. 964; Same (1903), 139 Cal. 325, 73 Pac. 864; Montague \& Co. v. Furness (1904), 145 Cal. 205, 78 Pac. 640; Hampton v. Christensen (1906), 148 Cal. 729, 84 Pac. 200; Martin v. McCabe (1913), 21 Cal. App. 658, 132 Pac. 606. In all of these cases action was brought on a bond given pursuant to Cal. Code Civ. Proc., \& 1203, and in each recovery was denied on the ground that the provision requiring the bond was unconstitutional, and the bond was without consideration.

Cf. Alaska Improvement Co. v. Hirsch (1897), 119 Cal. 249, 47 Pac. 124, where a common law bond was declared void for the same reascis, viz., not supported by consideration. A plaintiff was in this case required by order of the court to give a bond, supposedly to secure the continuance of a temporary restraining order. Recovery on this bond was denied on the ground that it did not "appear that the restraining order was continued in force at all by reason of the bond, or that by giving it the plaintiff in the injunction suit gained any advantage whatever. The order requiring the bond did not make the continuance of the restraint conditional upon giving the bond. ..."

s (1894), 103 Cal. 233, 37 Pac. 202. 
sion of the lands claimed at the commencement of the proceedings, upon giving a bond pursuant to section 1254 of the Code of Civil Procedure as it stood prior to 1880. Action was subsequently brought on this bond and recovery denied, the court declaring that the provision of the Code prescribing such a bond was unconstitutional, and the bond itself void.

A familiar illustration of the same rule is found in a line of cases beginning with People v. Cabannes, ${ }^{6}$ decided in 1862, which hold that where a bond is given to stay the execution of a judgment pending appeal, such bond is without consideration and no recovery will be allowed thereon, where it appears that execution might not have issued even though no bond had been given. Thus in Powers v. Chabot ${ }^{7}$ an appeal had been taken from a decree foreclosing a chattel mortgage and two bonds given by the appellant: one the ordinary appeal bond in the sum of three hundred dollars, and the other a stay bond in double the amount of the judgment. In an action on the stay bond recovery was denied, the court, after deciding that the appeal bond alone was sufficient to have stayed execution, saying:

"The undertaking was not given in pursuance of any agreement between the parties, but simply to secure a statutory privilege. It did not have that effect, and was therefore wholly without consideration and void, and could not be valid as a common-law undertaking."

In like manner the same rule was applied in the notable case of Loop Lumber Co. v. Van Loben Sels. ${ }^{8}$ There Van Loben Sels had contracted with the City and County of San Francisco to construct a sewer, and, believing that the Bond Act ${ }^{2}$ governed the proceedings, gave a bond inuring to the benefit of materialmen and laborers in the sum of $\$ 41,000$, as required by section 1 of that Act. Action was brought on this bond by an unpaid materialman, and judgment in the plaintiff's favor was reversed by the Supreme Court, upon an appeal taken by the surety alone.

6 (1862), 20 Cal. 525; Whitney v. Allen (1862), 21 Cal. 233; Powers v. Crane (1885), 67 Cal. 65, 7 Pac. 135; Central Lumber Co. v. Center (1895), 107 Cal. 193, 40 Pac. 334; Reay v. Butler (1897), 118 Cal. 113, 50 Pac. 375; Estate of Kennedy (1900), 129 Cal. 384, 62 Pac. 64; Olsen v. Birch \& Co. (1905), 1 Cal. App. 99, 81 Pac. 656.

7 (1892), 93 Cal. 266, 28 Pac. 1070.

8 (1916), 173 Cal. 228, 159 Pac. 600.

$\checkmark$ Cal. Stats. 1897 , p. 201 , as amended. 
The argument upon which the decision is bàsed is briefly as follows: Section 6, Article XI, of the Constitution of California makes the provisions of a freeholders' charter absolutely controlling in all "municipal affairs"; a contract for the construction of a sewer is a "municipal affair," and for the letting of such a contract the municipality may provide a complete scheme in its freeholders' charter. The City and County of San Francisco had in Article VI of its freeholders' eharter provided just such a complete scheme for the letting of such contracts, and had required of contractors a bond conditioned for the faithful performance of the contract, but none for the benefit of materialmen and laborers; therefore the Bond Act, which required a bond for the benefit of materialmen and laborers, and pursuant to which the bond in controversy had been given, was in conflict with such freeholders' charter and entirely inapplicable to these proceedings. Such bond, therefore, having been given solely to comply with the conditions imposed by such Act, was without consideration and void. The court says:

"We think that it must be concluded in view of the allegations of the complaint that the bond was given solely to secure the right on the part of the contractor to proceed with the performance of his contract with the City and County of San Francisco, on the theory that under the provisions of the act the giving of such a bond was essential before the contractor could proceed with such performance. If for any reason such right to proceed with the work existed independent of said act and could not be affected or impaired thereby, it would seem to follow under our decisions that the bond was without consideration and void."

The foregoing cases illustrate one use of the terni "statutory bond."10 For the sake of brevity these cases will hereafter be classified as type $I$.

10 This rule is carried still further in certain cases which hold that where a "statutory bond" contains certain provisions prescribed by statute and other provisions which the statute does not require to be inserted in the bond, the former will be held valid and the latter void as surplusage. Thus in Miles v. Baley (1915), $170 \mathrm{Cal}$. 151, $149 \mathrm{Pac}$. 45, it is said: "The fact that one of the conditions of the bond is that the contractors will faithfully execute the terms of their contract to the satisfaction of the school district-a requirement which is not prescribed by the statute in question -is not conceived to possess any importance in determining the character of the bond... Where a statute provides that an official bond shall be given in a certain penalty and contain 
The second sense in which the term "statutory bond" is used by the courts is illustrated by cases which hold that where a statute provides for the giving of a bond, the conditions imposed by such statute on the beneficiary of the bond must be strictly complied with by such beneficiary, if he is to recover on such bond. Thus in Miles v. Baley ${ }^{11}$ a bond, inuring to the benefit of materialmen and laborers, had been given by a building contractor upon his contracting to build a school house. Unpaid materialmen and laborers assigned their claims to the plaintiff, who brought action on this bond. The surety company contended that this was a bond given pursuant to the Bond Act, ${ }^{12}$ and that the claims sued on had not been filed as required by section 2 of that Act. The court approved of this contention, and recovery against the surety was denied. The court says:

"Obviously, if the instrument must or could, with legal propriety, be held to be a common-law bond, we would be required to hold that, to state a cause of action upon the bond in favor of the plaintiff, it was not essential for him to disclose by his complaint that his assignors had filed their claims with the board of trustees of said school district, as prescribed by section 2 of the act of 1897. And, $e$ converso, if the instrument is a statutory bond, it was manifestly essential for the plaintiff to show that all the requirements of the statute, vital to the support of an action upon the bond of materialmen, etc., had been observed by his assignors, and that the silence of the complaint respect-

certain provisions, if the principal and surety voluntarily enter into a bond in a greater penalty or which contains more onerous conditions, the bond will be binding at least to the extent of the statutory requirements. In such case the conditions in excess of the statutory requirements may be regarded as surplusage and the bond sustained as to the others.' (Brandt on Suretyship and Guaranty, 3d ed., sec. 617; ... . .)"

And in Lambert v. Haskell (1889), 80 Cal. 611, 22 Pac. 327, the court says: "For it is settled that a statutory undertaking beyond what is required by the statute is to that extent without consideration and inoperative. (Powers v. Crane, $67 \mathrm{Cal}$. 65; People v. Cabannes, $20 \mathrm{Cal}$. 525). The question is, therefore, what is the undertaking required by statute, and what liability does it impose?"

In People v. Barrett(1907), 6 Cal. App. 578, 92 Pac. 647, a bond, given upon an appeal from a judgment of imprisonment in a criminal case, was held void as a whole, on the ground that its terms were more onerous than required by the statute. This decision can doubtless be distinguished from the two preceding on the ground that here the provisions of the bond were wholly different from the statutory requirements, and not merely part surplusage. Cf. also Hensley v. School District No. 87 (1916), 97 Kans. 56, 154 Pac. 253.

11 (1915), 170 Cal. 151, 149 Pac. 45.

12 Supra, n. 9. 
ing that vital matter amounts to a total failure to state a cause of action upon the bond in favor of the plaintiff or his assignors."

To the same effect is the decision in Republic Iron \& Steel Co. v. Patillo, ${ }^{13}$ where a plaintiff, who had furnished material for street improvement work, was denied recovery upon a bond given pursuant to section $6 x / 2$ of the Vrooman Act, ${ }^{14}$ on the ground that he had failed to allege and the trial court had failed to find that he had filed a verified statement of his claim with the superintendent of streets within thirty days of the completion of the improvement. So in Hubbard v. Jurian ${ }^{15}$ the court refused to permit materialmen, who had not perfected their lien claims in the manner prescribed by the mechanics' lien law, to recover upon a bond given pursuant to section 1183 of the Code of Civil Procedure, saying:

"The bond was executed in response to the requirements of the statute. It is therefore a statutory bond in the strictest sense and under the familiar and well settled rule parties claiming the benefit of the obligation of the bond must show a substantial compliance with the conditions of the statute under which the bond was given."

The theory upon which these cases (which for convenience will hereafter be referred to as type II) are supported seems to be that a surety who executes a bond provided for by statute has a right to assume that all the conditions imposed by the statute upon the beneficiary of the bond will be faithfully performed by such beneficiary. It would doubtless be argued that the terms of the statute under which the bond is given become by implication a part of the surety's contract, or at least that a failure by the beneficiary to observe the conditions imposed upon him by the statute is an inequitable variation of the surety's risk, which will discharge the surety. ${ }^{16}$.

The only California decision which attempts to assign reasons

13 (1912), 19 Cal. App. 316, 125 Pac. 923.

1) Cal. Stats. 1885, p. 147 , as amended.

15 (Dec. 31, 1917), 26 Cal. App. Dec. 79.

16 The argument upon which these cases must be supported is not to be confused with the reason supporting the rule announced in cases which hold that judgment on motion will not be entered upon a stay bond on appeal under Cal. Code Civ. Proc., $\$ 942$, unless the bond strictly complics with all the requirements of that section, and such requirements are applicable to the facts of the particular case. These cases are: Powers v. Crane, supra, n. 10; McCallion v. Hibernia Society (1893), 
for the general rule followed in this type of case is Republic Iron \& Steel Co. v. Patillo. ${ }^{17}$ There the court says:

"It was necessary, in order that a cause of action might be stated, for the plaintiff to allege this fact and the court to make a finding thereon. It cannot be said that a compliance with the statutory requirement in this regard would prove of no benefit to the sureties, and that, therefore, it may be disregarded. The first answer that might be made to such a contention would be that where street improvement proceedings depend upon statutory provisions as giving authority to make such contracts, persons claiming the benefit of such provisions must make substantial compliance with the requirements thereof. The second answer that may be made is that as to the sureties the filing of the verified claim with the public officer showing that the bounden principal has failed to pay for materials, furnished a means of notice to such sureties and by timely action they may be able to protect themselves, where, without notice, their remedy might be lost."

It must be evident that these two uses of the term "statutory bond" cannot be blended in a single definition. An illustration will make this clear. Section 1183 of the Code of Civil Procedure declares that if a bond, in a sum equal to one-half the price stated in a building contract, and inuring to the benefit of materialmen and laborers, is filed together with the contract before the work under the contract commences, the court may, where it would be equitable to do so, restrict the amount of mechanics' liens recoverable in connection with such contract to the amount of the contract price remaining due from the owner of the property to the contractor. A bond given by a

98 Cal. 442, 33 Pac. 329; Central Lumber Co. v. Center and Reay v. Butler, supra, n. 6.

The theory upon which these cases are to be supported is that the statute permits a certain form of remedy (judgment on motion) only to plaintiffs who comply strictly with the requirements of the statute. In the cases under type II, on the other hand, the question at issue is not as to the nature of the remedy permitted, but rather the nature of the right created. This right arises not by statutory fiat, but out of contract.

17 Supra, n. 13. In Mangrum v. Truesdale (1900), 128 Cal. 145, 60 Pac. 775, a bond, inuring to the benefit of laborers and materialmen, was given pursuant to Cal. Code Civ. Proc., $\$ 1203$, but was not filed as required by such section. A recovery upon this bond was denied upon the ground that actual delivery of a bond of this character (for the benefit of an undetermined class) was impossible; that the filing required by the statute was a substitute for delivery; that since this bond had not been filed it had not been delivered and was for this reason void. This reasoning, however, does not seem to have been repeated in later cases. 
building contractor and surety pursuant to this section would not be a "statutory bond" in the sense described by the cases of type $I$. The building contractor is free to contract with the owner of the property, so far as the provisions of the mechanics' lien law are concerned, and no bond of this description is required of him as a condition precedent to entering into such contract. $\mathrm{He}$ does not secure the right to contract by executing such bond. If section 1183 were held unconstitutional, a building contractor who had given a bond of this description, would be in no position to urge, in the words of Loop Lumber Co. v. Van Loben Sels, ${ }^{18}$ "that the bond was given solely to secure a right on the part of the contractor to proceed with the performance of his contract." But on the other hand, a bond given pursuant to section 1183 is surely to be classified as a "statutory bond" in the sense in which that term is used in the cases of type II, and Hubbard v. Jurian, ${ }^{29}$ is authority in point. It was there held, as already noted, that if recovery were to be allowed on a bond given pursuant to section 1183 of the Code of Civil Procedure, it must appear that the requirements of the statute had been fully complied with by the beneficiary of the bond. In other words, "statutory bonds" described by the cases of type II comprise all bonds given pursuant to a statute, whereas the "statutory bonds" described by the cases of type I comprise only bonds given pursuant to a statute which makes the execution of a bond a condition precedent to the acquisition of a privilege.

Whether or not a bond is a common law or "statutory" obligation is a question which has called forth no little judicial discussion, and in more than one case has been a vital issue. For example, suppose that Smith enters into a contract with a certain county to build a court house, and that a certain statute

18 Supra, n. 8.

10 Supra, n. 15. In this case it was held that materialmen, seeking recovery on a bond given pursuant to Cal. Code Civ. Proc., $\$ 1183$, must prove that they have filed verified claims of lien pursuant to Cal. Code Civ. Proc., $\S 1187$. Compare this with Hammond Lumber Co. v. Willis (1915), 171 Cal. 565, 153 Pac. 947, which allowed recovery on a bond given pursuant to section 1183 even though such bond had not been filed as provided by section 1187. This may perhaps be distinguished from Hubbard v. Jurian on the ground that the filing of the bond is not a duty imposed on the beneficiary of the bond; that therefore the surety cannot urge that he is entitled to have the bond filed, and that a failure to file the same is an inequitable variation of his risk by an act of the beneficiary; whereas the filing of a verified claim of lien is a duty imposed upon the beneficiaries of such bond, i.e., materialmen and laborers, and therefore a duty the performance of which the surety is entitled to rely upon. 
either (1) requires a bond from the contractor as a condition precedent to entering into this contract or (2) provides that the contractor may give a bond. If the statute is of the former character and for any reason is declared unconstitutional or inapplicable to the case at bar, or if the statute is of either character and the beneficiary of the bond has not complied with the requirements which such statute makes of him, the beneficiary will probably urge that he is nevertheless entitled to recover on the bond as a common law undertaking. ${ }^{20}$ Doubtless this question should be answered by determining the intention of the parties, i. e., if the obligors named in the bond intended to comply with the statute it should be declared to be a "statutory bond"; if they did not, it should be held to be a common law obligation. The following excerpts from cases in which this question was

20 A line of cases following Kiessig v. Allspaugh (1891), 91 Cal. 234, 27 Pac. 662, will usually be cited whenever it is urged that a given instrument is a common law bond. These cases arose upon bonds given to protect a property owner, who had contracted for the erection of a building on his land, against claims on account of material and labor furnished in connection with such contract. At the time these cases were decided, Cal. Code Civ. Proc., $\$ 1183$ (Cal. Stats. 1885, p. 143) provided that where the price named in a building contract exceeded $\$ 1000$, the building contract should be recorded and if not recorded should be "wholly void." In these cases the building contract had not been recorded, and it was urged that since the contracts were therefore void, the bonds, upon which recovery was sought, were also void as having been given to secure the performance of void contracts. The court, however, in each case allowed recovery, pointing out that the covenant in the bonds for the payment of labor and material claims had no connection with the performance or non-performance of the contracts, and was supported by other consideration. As the court in Kiessig v. Allspaugh says, the purpose of the bond "is not to secure to plaintiff reimbursement for any damage, the right to recover which rests alone upon the building contract." It is to be noted that in these cases the bond could not be described as a "statutory bond" of either type, since Cal. Code Civ. Proc., $\S 1183$, did not in terms provide for any bond at all, and hence these bonds could not have been given pursuant to statutory requirement or permission. The cases thus referred to are: Kiessig v. Allspaugh, supra; Blyth v. Robinson (1894), 104 Cal. 239, 37 Pac. 904; McMenomy v. White (1896), 115 Cal. 339, 47 Pac. 109; Summerton v. Hanson (1897), 117 Cal. 252, 49 Pac. 135; Watterson v. Owens River Canal Co. (1914), 25 Cal. App. 247, 143 Pac. 90.

Another familiar line of cases in which the undertaking was declared to be a common law bond are those wherein it is held that although the undertaking is not in the form required by the Code for releasing property from attachment, yet if it is voluntarily given and does in fact procure the release of property from attachment, it is valid. Palmer v. Vance (1859), 13 Cal. 553; Smith v. Fargo (1881), 57 Cal. 157; Gardner v. Donnelly (1890), 86 Cal. 367, 24 Pac. 1072; Bailey v. Aetna Indemnity Co. (1907), 5 Cal. App. 740, 91 Pac. 416; Kanouse v. Brand (1909), 11 Cal. App. 669, 106 Pac. 120.

See also, Baker v. Bartol (1857), 7 Cal. 55i; Alaska Improvement Co. v. Hirsch (1897), 119 Cal. 249, 47 Pac. 124. 
squarely presented show what circumstances the courts will rely upon as indicating, doubtless, that the obligors intended that the bond in a given case should comply with the statute:

"The bond itself makes no express reference to the statute or by any language pretends to discover the source from which it comes, and it is, therefore, manifest that the vital question submitted here must largely be determined upon the wording of the bond or by comparing its language with that of the statute. ....

"Comparing the undertaking with the statue, it will readily be noted that that part of the former which specifies the conditions to be fulfilled by the contractors to render the undertaking inoperative or without effect is in the precise language of the statute. It is also to be observed that the amount of the bond is approximately that prescribed and required by the statute. There is no conceivable substantial difference, in substance and legal effect, between the conditions of the bond and those prescribed by the statute. Moreover, the presumption is that the board of trustees, as a public official body, performed every duty imposed upon it by law, and that, therefore, it exacted from the contractors the bond required by the statute in such cases. ....

"It is obviously not necessary that the bond should expressly refer to the statute in order to constitute it a statutory bond. A bond, though not in the words of the statute requiring it to be given, if its substance and legal effect is the same as the form prescribed by such statute, is a statutory bond. ....."21

"While the bond does not expressly declare that it is given pursuant to said section, the facts in the case clearly show that it was. It is alleged in the complaint (all the allegations of which in the agreed case are found to be true) that this bond "by the provisions of section 1203 of the Code of Civil Procedure .... was made to inure to the benefit of all persons .... furnishing materials to be used in the construction of said building.' It is conditioned in a penalty of twenty-four hundred dollars, which appears to be twenty-five per cent of the contract price, as the said section requires. The general clause in the bond under which appellant claims, - to wit, "This bond and undertaking shall inure,' etc., is a bodily excerpt from said section. The bond was filed with, and at the same time, the building contract was filed, as the section provides it must be, and the briefs of appellant discuss, and uphold it, as a bond given under such section, while at the same time claiming that if

21 Miles v. Baley, supra n. 10. 
not available as a statutory bond, it is nevertheless good as a common-law obligation. ...."22

"The bond, as to its terms and conditions, was precisely the undertaking contemplated by section 1203 of the Code of Civil Procedure. It referred to the builder's contract; was for an amount 'equal to at least twenty-five per cent of the contract price hereinafter referred to'; by its terms it was made to inure to the benefit of any and all persons who might perform labor or furnish materials to the contractor, and was to remain in full force and effect if the contractor did not fully pay to any and all persons the value of the labor or materials furnished by them, or any of them. It is clearly, then, the undertaking called for by section 1203. ...."23

"While it was not alleged in the complaint, nor made the subject of any finding by the court, that the bond was given under the authority of statute, considering that the municipality was only authorized to act under permission of statutory authority in making the street improvement, and further, that the bond in its terms was phrased according to the statutory requirement, it must be assumed that the contract was so made and the bond given in connection therewith accordingly."2

An examination of all the circumstances of each case in this way is unnecessary where the bond itself recites that it is given to comply with a certain statute. Such recital seems to be regarded as at least prima facie evidence that the bond is "statutory" and not a common law obligation. ${ }^{25}$

An interesting question, which may arise in connection with the cases of type $I$, is whether or not recitals may be inserted in the bond which will estop the surety from setting up the

22 San Francisco Lumber Co. v. Bibb, supra, n. 4.

23 Mangrum v. Truesdale, supra, n. 17.

2* Republic Iron \& Steel Co. y. Patillo, supra, n. 13. See also Martin v. McCabe, supra, n. 4. In this case the bond recited that it should be "construed as a common-law bond in favor of said W. A. Bean and L. O. Stephens." Bean and Stephens were property owners and the bond was conditioned for the payment of marerial and labor claims against their property in connection with a certain building contract. It was held that this was a bond given pursuant to Cal. Code Civ. Proc., \& 1203 . In the opinion it is said: "In accordance with a familiar rule of interpretation, the recital as to the undertaking being construed as a common law bond in favor of said W. A. Bean and L. O. Stephens, the owners of the building, who are not parties to this action, is also a circumstance confirmatory of the position that as to the other parties the instrument was intended to be a statutory bond."

25 San Francisco Lumber Co. v. Bibb, supra, n. 4; Shaughnessy v. American Surety Co., supra, n. 1; Martin y. McCabe, supra, n. 4; Loop Lumber Co. v. Van Loben Sels, supra, n. 8. 
defense that the statute requiring the bond does not apply to the particular facts presented, and that the bond is therefore unnecessary, without consideration, and void. In other words, suppose that in a case similar to Loop Lumber Co. v. Van Loben Sels, ${ }^{28}$ the bond contained a recital that the Bond Act was binding upon the contracting parties, could the surety on such bond plead that the Bond Act did not govern the proceeding? In Live Oak Lumber Co. v. Farr, ${ }^{27}$ reliance upon a recital of a legal conclusion appears to have furnished the basis for an estoppel. The court says:

"There is no merit in the contention that by specific averment it should appear that the city was authorized to order the work done. The contract of suretyship upon which the action was brought contains this provision: 'The condition of the above obligation is such that, whereas, the board of trustees of the city of Gridley, a municipal corporation of the sixth class, of the county of Butte, state of California, has heretofore awarded a contract to the above-named principal to do and perform the following work in said city of Gridley:.... Now, therefore, if the above bounden William F. Farr fails to pay for any material or supplies furnished for the said work contracted to be done, or for any work or labor thereon of any kind, the sureties on this bond will pay the same.' Having recited in their understanding the execution of said contract, and, upon the strength of said recital, having induced materialmen to deliver material to be used under said contract, the sureties are estopped from saying that the contract was invalid."28

On the other hand, in Estate of Kennedy, ${ }^{20}$ which held that a stay bond given upon an appeal from a decree of distribution was unnecessary and therefore without consideration and void, the court says:

${ }^{26}$ Supra, n. 8.

27 (1915), 28 Cal. App. 641, 153 Pac. 741.

28 Accord: McMillan v. Dana (1861), 18 Cal. 339; Smith v. Fargo, supra, n. 20; Pierce v. Whiting (1883), 63 Cal. 538; Bairey v. Aetna Indemnity Co., supra, n. 20; Hammond v. U. S. Fidelity \& Guaranty Co. (1916); 29 Cal. App. 464, 468, 155 Pac. 1023.

In People v. Jenkins (1861), 17 Cal. 500; People v. Fudson (1889), 78 Cal. 154; 20 Pac. 369; and Moore v. Earl (1891), 91 Cal. 632, 27 Pac. 1087, the surety was held estopped by recitals in the bond of a public official to deny the lawful appointment of such official.

In Kiessig v. Allspaugh, supra, n. 20 , it was salc: " $\ldots$ if, in order to support this action, it is necessary that the bond should be based upon a valid building contract, we should hold that the appellant is estopped to dispute the truth of the particular recital contained in the bond as to such fact."

29 (1900), 129 Cal. 384, 62 Pac. 64. 
"When want of consideration is pleaded there is no estoppel, whatever the terms of the instrument may be, which can interfere with that defense. The idea of such estoppel comes down to us from the days of sealed instruments. Seals were abolished by the code (Civ. Code, sec. 1629), and that there is a good and sufficient consideration for an instrument in writing is expressly made a disputable presumption which may be controverted by other evidence. (Code Civ. Proc. sec. 1963.)"

And in Alaska Improvement Co. v. Hirsch, ${ }^{30}$ where a bond, given by a plaintiff supposedly to secure the continuance of a temporary restraining order, was held void on the ground that it did not appear that the restraining order was continued in force by reason of such bond, the court says:

"Here, the giving of a bond was not made to effect the continuance of a restraint, therefore the continuance of the restraint could not have been a consideration for the bond, even though it had been so recited in the bond."

The foregoing classification, though doubtless imperfect in some details, will at least have shown the danger of reasoning: (1) that a given instrument complies with certain objective standards; (2) that because it complies with such standards it it a "statutory bond"; (3) that because it is a "statutory bond" certain results may inevitably be taken for granted. Whether or not an undertaking is a "statutory bond" of either type must depend upon the intention of the parties, such intention being determined from an examination of the circumstances of each case-at best a method of classification which defies exact definition. Having decided that a given instrument is a "statutory bond", because it was the intention of the parties that it should comply with the provisions of a given statute, its validity will often depend upon whether or not the statute requires the bond to be executed as a condition precedent to the acquisition of some privilege. Finally, wherever a bond is given to comply with a statute, the performance which the statute requires of the beneficiary of the bond must be proved before such beneficiary will be allowed to recover. This requires in every case a careful examination of the statute.

John M. Hall.

Los Angeles, California.

30 (1897), 119 Cal. 249, 47 Pac. 124, 51 Pac. 340. 